
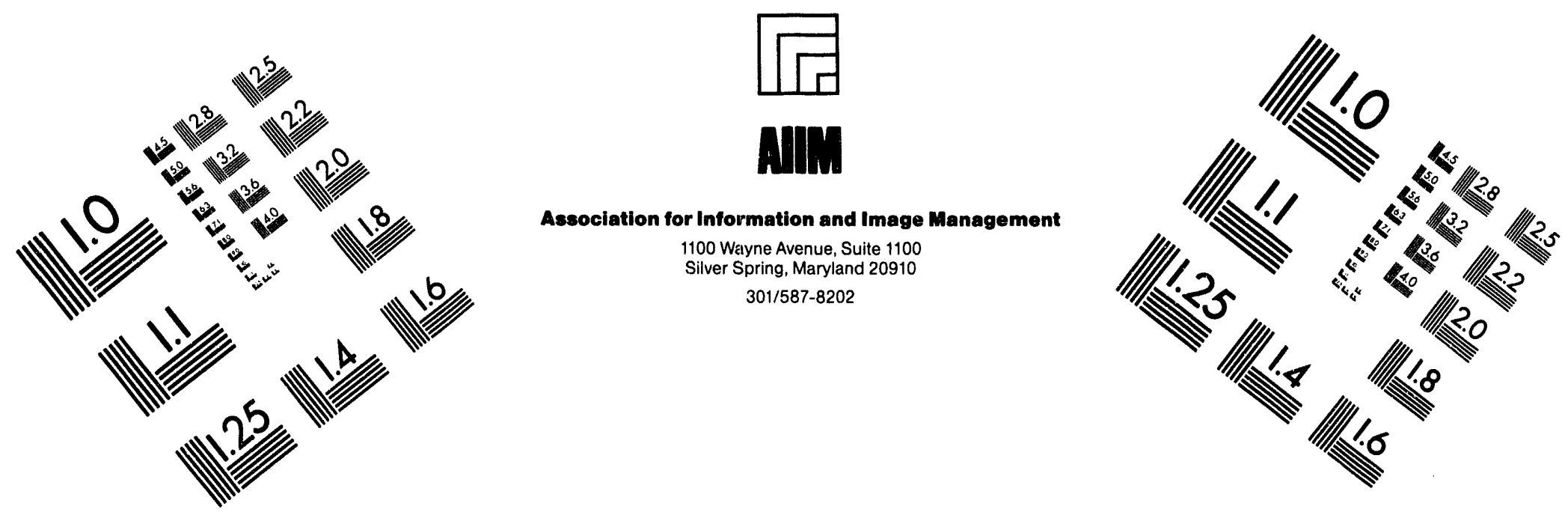

\title{
Centimeter
}

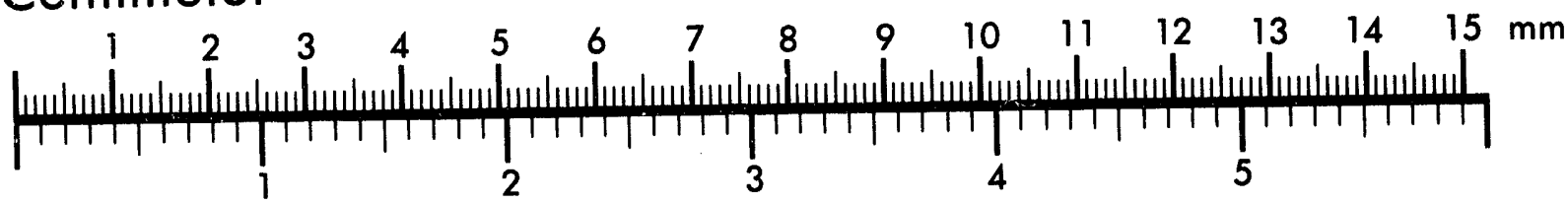
Inches
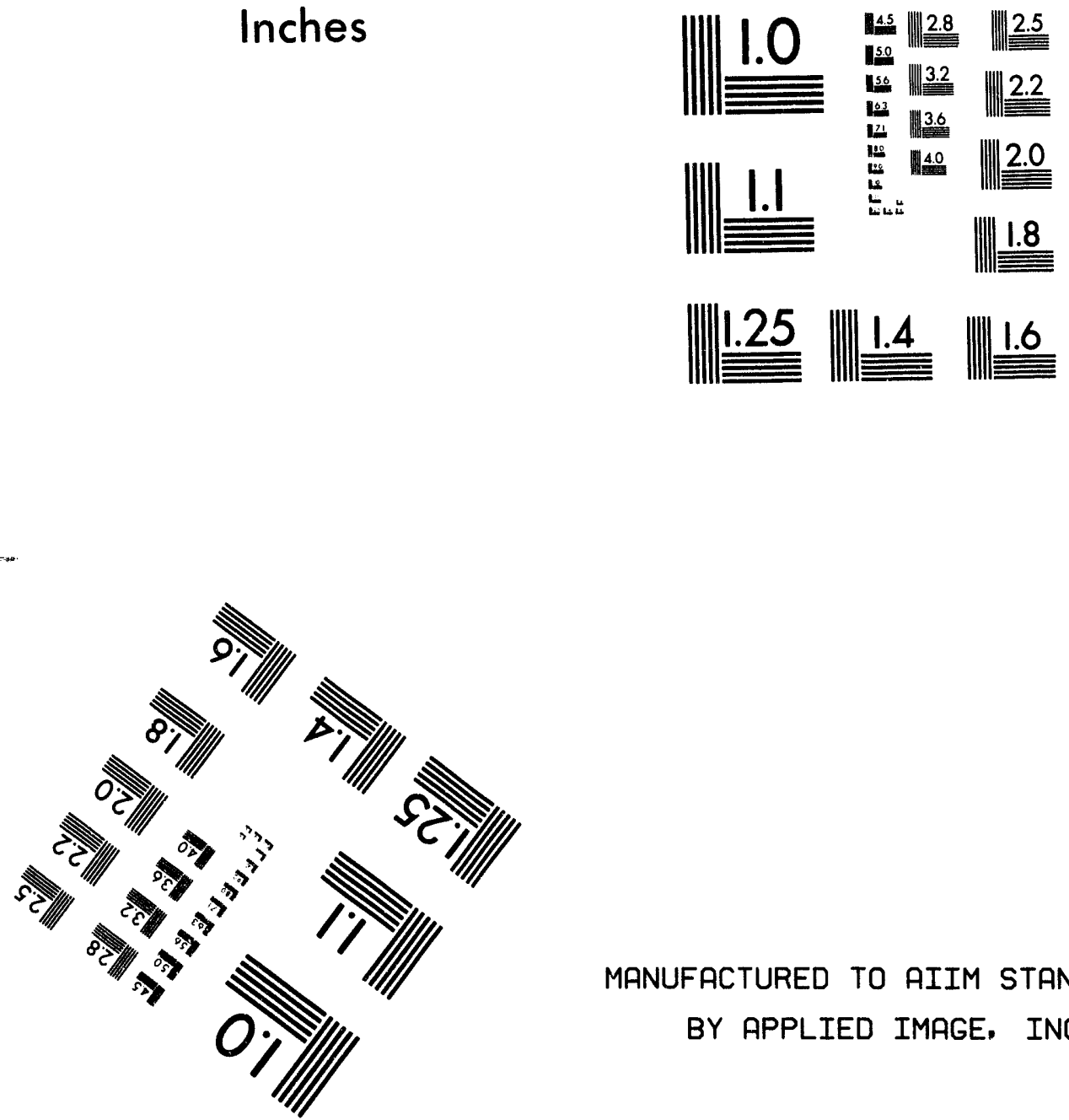

MANUFACTURED TO AIIM STANDARDS

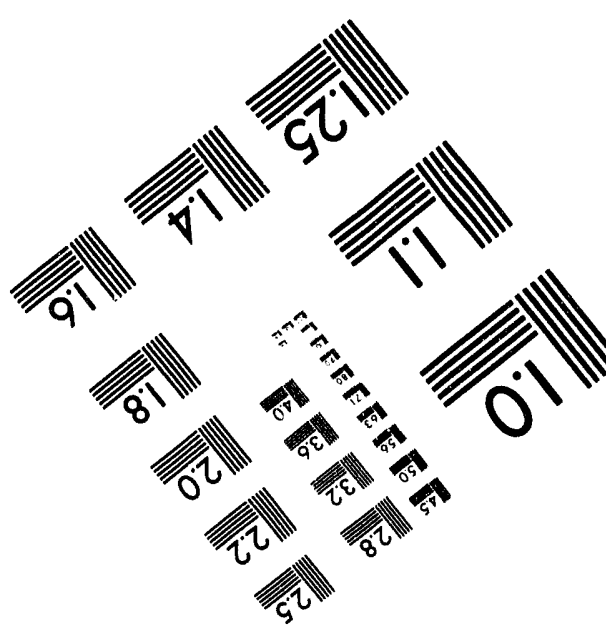



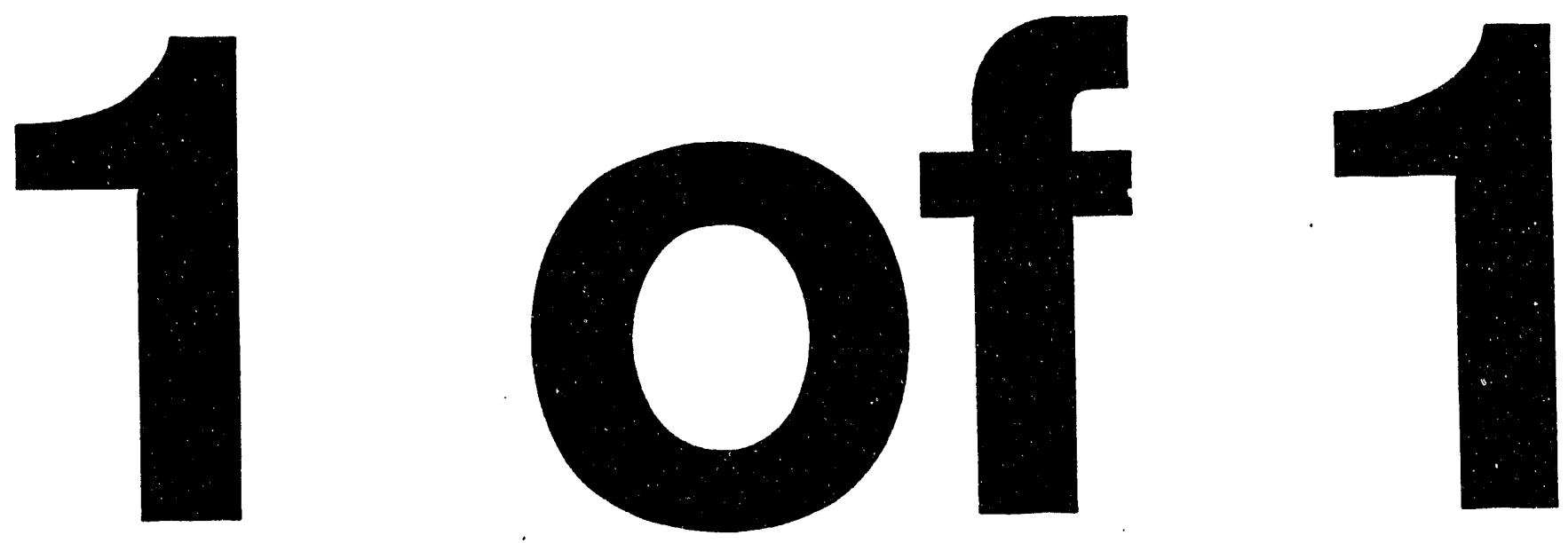


\title{
Project Management Plan \\ for the \\ Idaho National Engineering Laboratory \\ Waste Isolation Pilot Plant \\ Experimental Test Program
}

\author{
M. J. Connolly \\ D. L. Sayer
}

Published November 1993

Idaho National Engineering Laboratory

EG\&G Idaho, Inc.

Idaho Falls, Idaho 83415 


\section{Project Management Plan for the \\ Idaho National Engineering Laboratory Waste Isolation Pilot Plant Experimental Test Program}

Approved by:

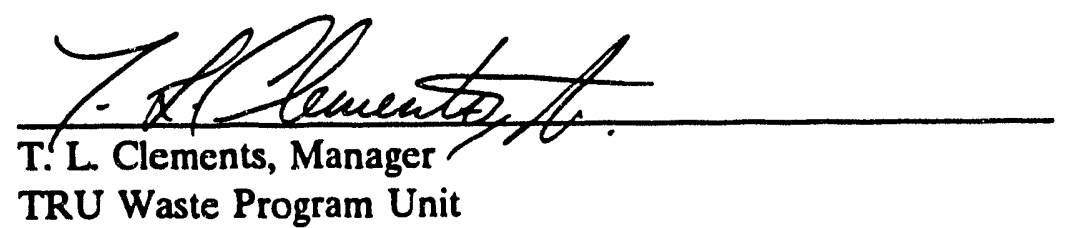




\begin{abstract}
The Idaho National Engineering Laboratory (INEL) Waste Isolation Pilot Plant (WIPP) provides support to the WIPP Project in achieving a final disposal decision for the WIPP. Physical, chemical, and radiological data on INEL retrievably-stored transuranic (TRU) waste will be collected to support the WIPP's compliance demonstration with 40 CFR 191, 40 CFR 264, and 40 CFR 268.

The INEL WETP is a joint program supported by EG\&G Idaho, Inc. and Argonne National Laboratory-West (ANL-W). Funding for the INEL WETP is provided by the U.S. Department of Energy Albuquerque Operations Office (DOE-AL)/WIPP Project Integration Office (WPIO) and as a result, the program is required to meet Department of Energy Idaho Operations Office and WPIO Program requirements. The INEL WETP program is managed by the EG\&G Idaho TRU Waste Programs Unit.

This plan documents the specific INEL WETP produrts, deliverable, and activities that will be completed to meet program objectives. Activities conducted at ANL-W in support of the INEL WETP are not addressed in this plan. Organization, work breakdown structure, management controls and reporting requirements, and change control process are described.
\end{abstract}




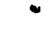




\section{CONTENTS}

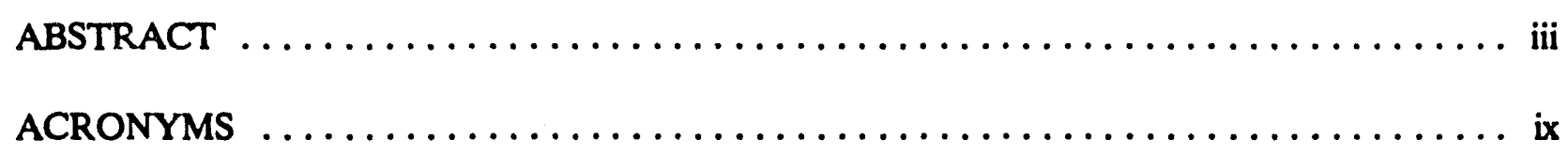

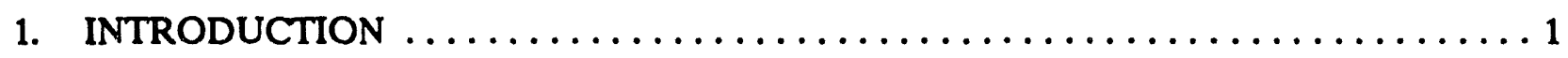

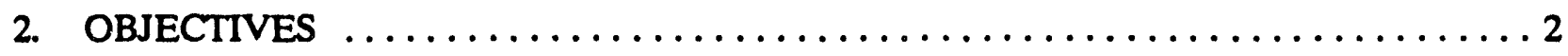

3. ORGANIZATION, RESPONSIBILITIES, AND AUTHORITY $\ldots \ldots \ldots \ldots \ldots \ldots 3$

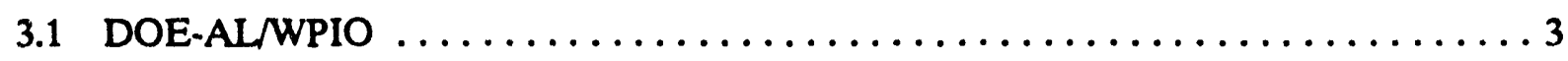

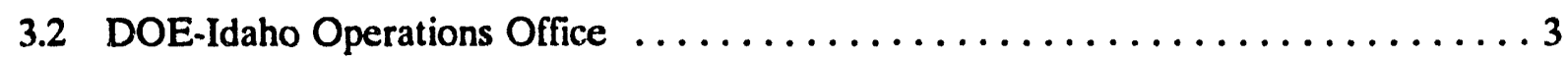

3.3 INEL WETP Site Project Office $\ldots \ldots \ldots \ldots \ldots \ldots \ldots \ldots \ldots \ldots \ldots \ldots$

3.4 Radioactive Waste Management Complex $\ldots \ldots \ldots \ldots \ldots \ldots \ldots \ldots \ldots \ldots$

3.5 EG\&G Idaho Environmental Chemistry Laboratory $\ldots \ldots \ldots \ldots \ldots \ldots \ldots \ldots$

3.6 EG\&G Idaho Engineering Research and Applications $\ldots \ldots \ldots \ldots \ldots \ldots \ldots$

3.7 EG\&G Idaho Nuclear and Radiation Physics $\ldots \ldots \ldots \ldots \ldots \ldots \ldots \ldots \ldots$

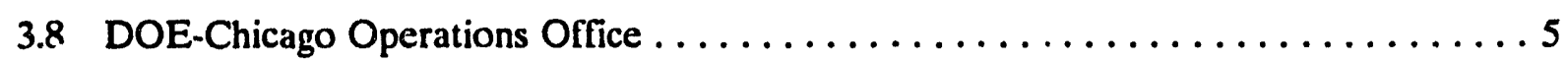

3.9 ANL-W WETP Project Manager $\ldots \ldots \ldots \ldots \ldots \ldots \ldots \ldots \ldots \ldots \ldots \ldots$

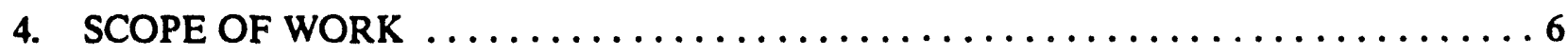

4.1 Operational Phase Waste Characterization $\ldots \ldots \ldots \ldots \ldots \ldots \ldots \ldots \ldots, \ldots$

4.1.1 Drum Selection and Retrieval $\ldots \ldots \ldots \ldots \ldots \ldots \ldots \ldots \ldots \ldots \ldots$

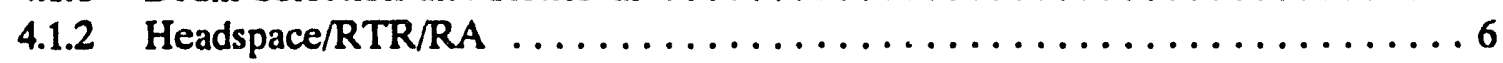

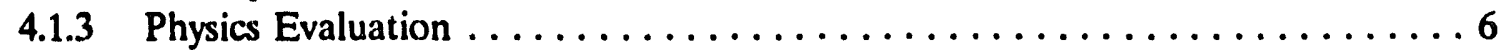

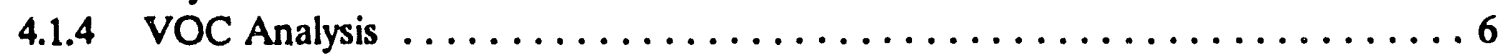

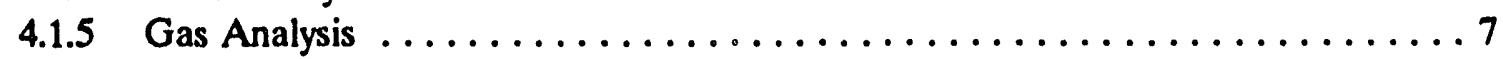

4.1.6 Reporting, Validation, and Documentation $\ldots \ldots \ldots \ldots \ldots \ldots \ldots \ldots$

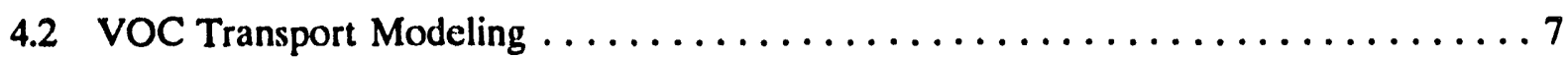

4.2.1 Drum Selection and Retrieval $\ldots \ldots \ldots \ldots \ldots \ldots \ldots \ldots \ldots \ldots, \ldots \ldots \ldots$

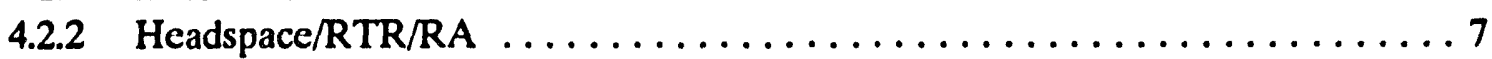

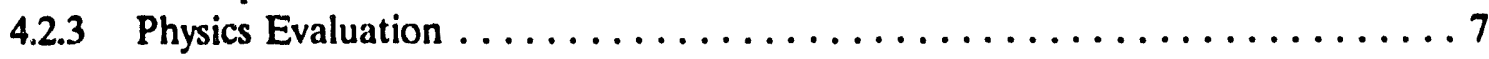

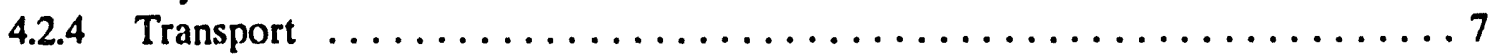




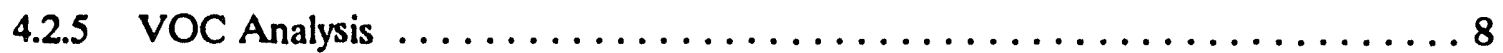

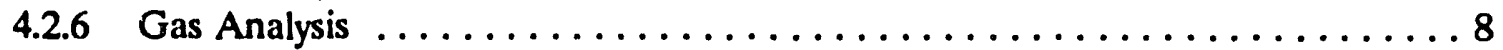

4.2.7 Reporting, Validation, and Documentation $\ldots \ldots \ldots \ldots \ldots \ldots \ldots \ldots$

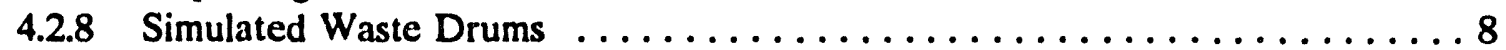

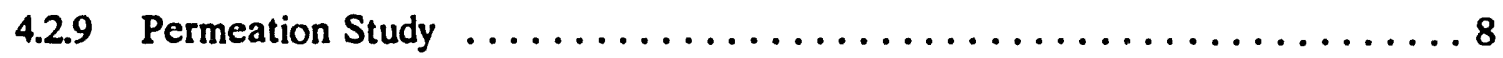

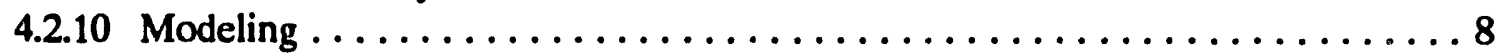

4.3 Waste Characterization Technology Developments $\ldots \ldots \ldots \ldots \ldots \ldots \ldots$

4.3.1 FT-IR $\ldots \ldots \ldots \ldots \ldots \ldots \ldots \ldots \ldots \ldots \ldots \ldots \ldots \ldots \ldots \ldots \ldots$

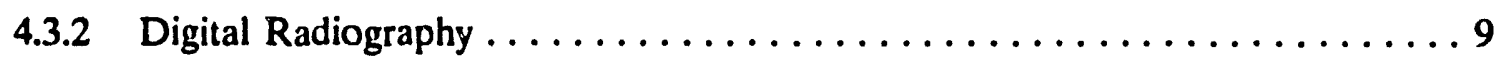

4.3.3 Solidified Waste Form Characterization $\ldots \ldots \ldots \ldots \ldots \ldots \ldots \ldots, \ldots$

4.4 Project Management/SPO $\ldots \ldots \ldots \ldots \ldots \ldots \ldots \ldots \ldots \ldots \ldots \ldots \ldots \ldots$

4.4.1 Technical Management $\ldots \ldots \ldots \ldots \ldots \ldots \ldots \ldots \ldots \ldots \ldots \ldots \ldots$

4.4.2 Project Control $\ldots \ldots \ldots \ldots \ldots \ldots \ldots \ldots \ldots \ldots \ldots \ldots \ldots \ldots, 10$

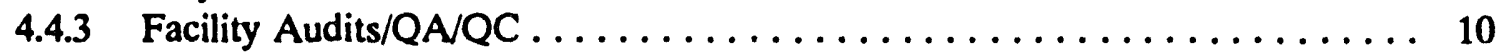

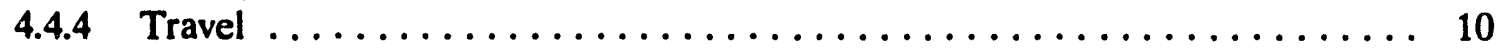

4.4.5 Management Reserve $\ldots \ldots \ldots \ldots \ldots \ldots \ldots \ldots \ldots \ldots \ldots \ldots \ldots 10$

4.5 Deliverables $\ldots \ldots \ldots \ldots \ldots \ldots \ldots \ldots \ldots \ldots \ldots \ldots \ldots \ldots \ldots \ldots \ldots, 11$

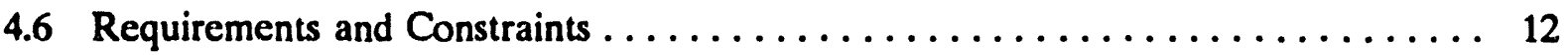

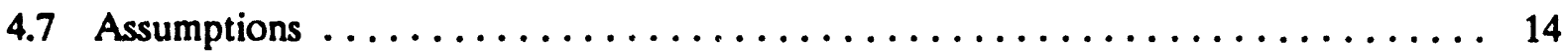

4.7.1 Operational Phase Waste Characterization $\ldots \ldots \ldots \ldots \ldots \ldots \ldots \ldots 14$

4.7.2 VOC Transport Modeling ........................ 14

4.7.3 Waste Characterization Technology Development $\ldots \ldots \ldots \ldots \ldots \ldots \ldots 14$

4.7.4 Project Management ............................ 14

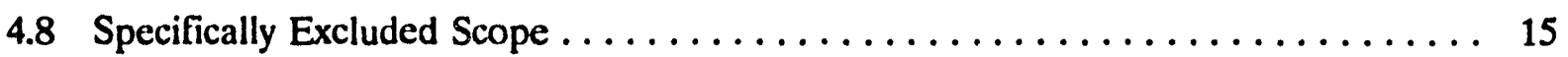

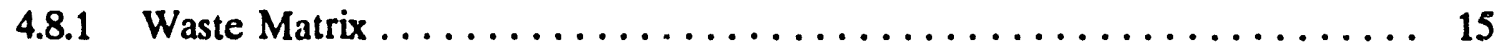

4.8.2 Affected Scheduled Facility Projects $\ldots \ldots \ldots \ldots \ldots \ldots \ldots \ldots \ldots, 15$

4.8.3 Boxed Waste .................................. 15

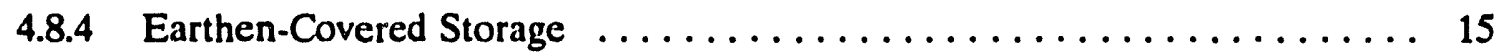

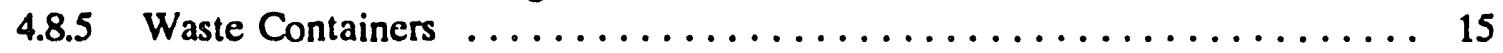

5. WORK BREAKDOWN STRUCTURE $\ldots \ldots \ldots \ldots \ldots \ldots \ldots \ldots \ldots \ldots \ldots \ldots \ldots \ldots \ldots$

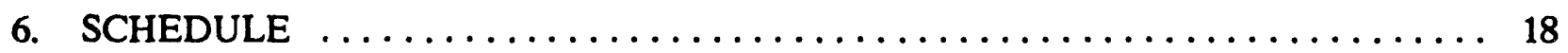

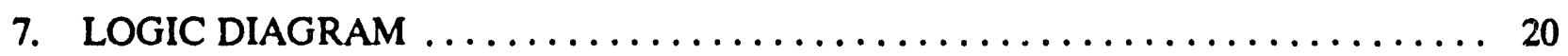

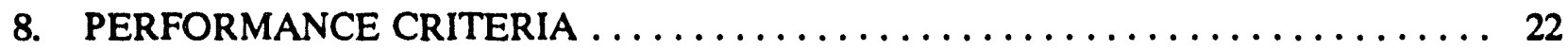


9. COST AND MANPOWER ESTIMATES $\ldots \ldots \ldots \ldots \ldots \ldots \ldots \ldots \ldots \ldots \ldots \ldots \ldots$

10. PROJECT FUNCTIONAL SUPPORT REQUIREMENTS $\ldots \ldots \ldots \ldots \ldots \ldots \ldots .24$

11. PROJECT MANAGEMENT, MEASUREMENTS, AND PLANNING AND CONTROL SYSTEMS $\ldots \ldots \ldots \ldots \ldots \ldots \ldots \ldots \ldots \ldots \ldots \ldots \ldots \ldots \ldots \ldots \ldots \ldots \ldots \ldots, 25$

12. INFORMATION AND REPORTING $\ldots \ldots \ldots \ldots \ldots \ldots \ldots \ldots \ldots \ldots \ldots \ldots, 26$

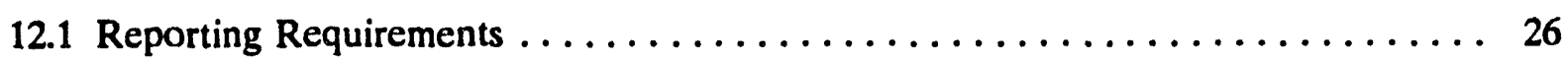

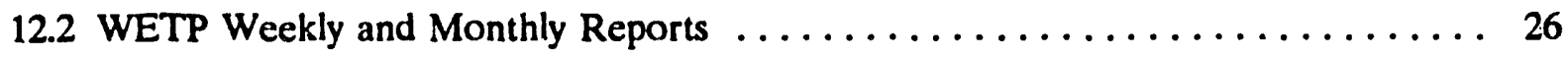

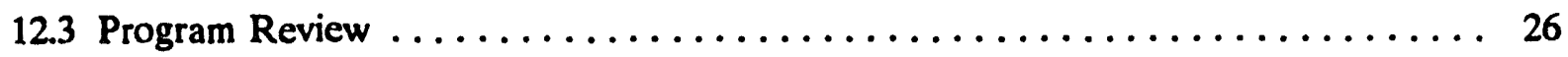

12.4 Formal and Informal Communications $\ldots \ldots \ldots \ldots \ldots \ldots \ldots \ldots \ldots \ldots$

13. SYSTEM ENGINEERING MANAGEMENT PLAN $\ldots \ldots \ldots \ldots \ldots \ldots \ldots \ldots . \ldots \ldots$

14. CONFIGURATION MANAGEMENT $\ldots \ldots \ldots \ldots \ldots \ldots \ldots \ldots \ldots \ldots \ldots \ldots \ldots$

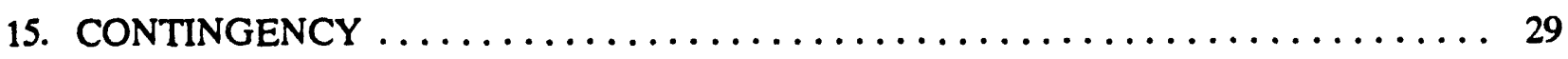

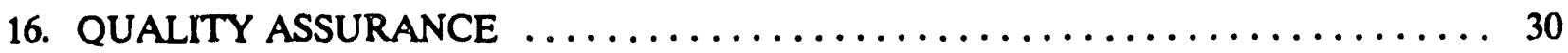

17. UTILITY SERVICES $\ldots \ldots \ldots \ldots \ldots \ldots \ldots \ldots \ldots \ldots \ldots \ldots \ldots \ldots \ldots \ldots \ldots \ldots$

18. DECISION RESPONSIBILITY MATRIX $\ldots \ldots \ldots \ldots \ldots \ldots \ldots \ldots \ldots \ldots \ldots \ldots \ldots \ldots \ldots$

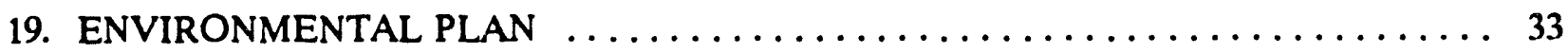

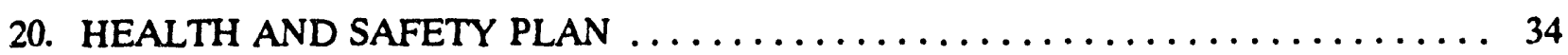

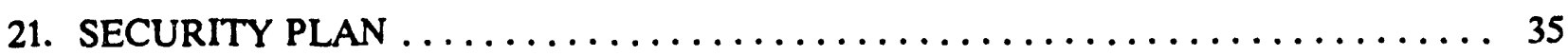

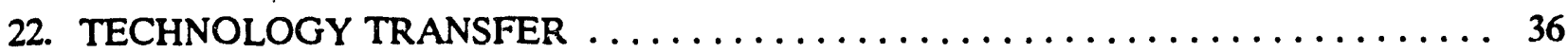

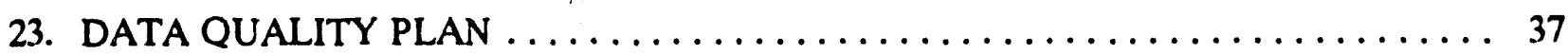

24. ACQUISITION AND ASSISTANCE PLAN $\ldots \ldots \ldots \ldots \ldots \ldots \ldots \ldots \ldots \ldots \ldots$

25. TEST AND EVALUATION PLAN $\ldots \ldots \ldots \ldots \ldots \ldots \ldots \ldots \ldots \ldots \ldots \ldots \ldots \ldots$

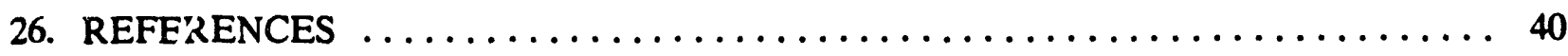




\section{FIGURES}

3-1. Organization responsibility chart $\ldots \ldots \ldots \ldots \ldots \ldots \ldots \ldots \ldots \ldots \ldots \ldots \ldots \ldots$

5-1. Work breakdown structure $\ldots \ldots \ldots \ldots \ldots \ldots \ldots \ldots \ldots \ldots \ldots \ldots \ldots \ldots \ldots$

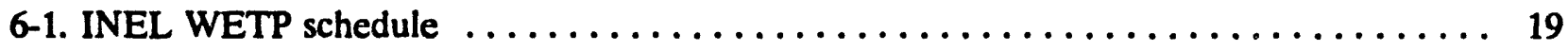

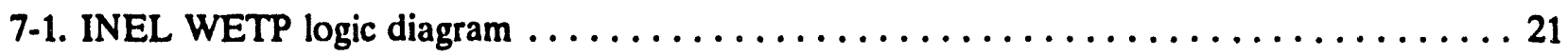

\section{TABLES}

4-1. Operational phase waste characterization $\ldots \ldots \ldots \ldots \ldots \ldots \ldots \ldots \ldots \ldots \ldots$

4-2. VOC transport modeling $\ldots \ldots \ldots \ldots \ldots \ldots \ldots \ldots \ldots \ldots \ldots \ldots \ldots \ldots \ldots \ldots$

4-3. Waste characterization technology development $\ldots \ldots \ldots \ldots \ldots \ldots \ldots \ldots \ldots \ldots$

4-4. Program management $\ldots \ldots \ldots \ldots \ldots \ldots \ldots \ldots \ldots \ldots \ldots \ldots \ldots \ldots \ldots \ldots$

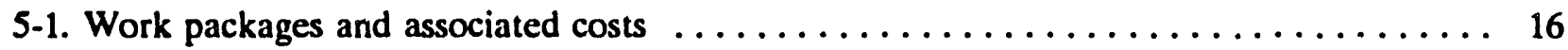




\section{ACRONYMS}

DS activity data sheet

AL Analytical Laboratory (ANL-W)

ANL-W Argonne National Laboratory-W

ASME

C\&S

American Society of Mechanical Engineers

CCB

certified \& segregated

CFR

Change Control Board

DOE

Code of Federal Regulations

DOE-AL

U.S. Department of Energy

DOE-CH

Department of Energy, Albuquerque Operations Office

DOE-HQ

Department of Energy, Chicago Operations Office

DOE-ID

DVF

Department of Energy Headquarters

ECL

Department of Energy, Idaho Operations Office

Drum Venting Facility

EDF

EG\&G Idaho Environmental Chemistry Laboratory

Engineering Design File

EPA

U.S. Environmental Protection Agency

ERA

EG\&G Idaho Engineering Research and Applications

ER\&WM

FT-IR

FY

GC

HFEF

Environmental Restoration \& Waste Management

Fourier Transform Infrared Spectroscopy

IDC

INEL

IRC

LDR

MS

fiscal year

gas chromatograph $(y)$

Hot Fuel Examination Facility

item description code

Idaho National Engineering Laboratory

NDA

NDE

NMD

Idaho National Engineering Laboratory Research Center

land disposal restriction

mass spectroscopy

nondestructive assay

nondestructive examination

NMVP

NQA

No-Migration Determination

PA

PAN

PD

PDP

PMP

QA

No-Migration Variance Petition

Nuclear Quality Assurance

Performance Assessment

Passive Active Neutron

Project Directive

Performance Demonstration Program

Project Management Plan

QAPjP

QAPP

QC

QPP

RA

quality assurance

Quality Assurance Project Plan

Quality Assurance Program Plan

quality control

Quality Program Plan

RCRA Resource Conservation and Recovery Act

RTR

real-time radiography 


$\begin{array}{ll}\text { RWMC } & \text { Radioactive Waste Management Complex } \\ \text { SARP } & \text { Safety Analysis Report for Packaging } \\ \text { SPO } & \text { INEL Site Project Office } \\ \text { SQAO } & \text { Site Quality Assurance Officer } \\ \text { SWEPP } & \text { Stored Waste Examination Pilot Plant } \\ \text { TDD } & \text { Task Description Documentation } \\ \text { TRU } & \text { transuranic } \\ \text { TRUPACT-II } & \text { Transuranic Package Transporter-II } \\ \text { VOC } & \text { volatile organic compound } \\ \text { WAC } & \text { Waste Acceptance Criteria } \\ \text { WACCC } & \text { Waste Acceptance Criteria Certification Committee } \\ \text { WAP } & \text { Waste Analysis Plan } \\ \text { WBS } & \text { Work Breakdown Structure } \\ \text { WCC } & \text { Waste Characterization Chamber } \\ \text { WETP } & \text { WIPP Experimental Test Program } \\ \text { WIPP } & \text { Waste Isolation Pilot Plant } \\ \text { WPIO } & \text { WIPP Project Integration Office } \\ \text { WWCP } & \text { WIPP Waste Characterization Program Plan }\end{array}$




\section{Project Management Plan for the \\ Idaho National Engineering Laboratory \\ Waste Isolation Pilot Plant Experimental Test Program}

\section{INTRODUCTION}

EG\&G Idaho, Inc. and Argonne National Laboratory-West (ANL-W) are participating in the Idaho National Engineering Laboratory's (INEL's) Waste Isolation Pilot Plant (WIPP) Experimental Test Program (WETP). The purpose of the INEL WETP is to provide chemical, physical, and radiochemical data on transuranic (TRU) waste to be stored at WIPP. The waste characterization data collected will be used to support the WIPP Performance Assessment (PA), development of the disposal No-Migration Variance Petition (NMVP), and to support the WIPP disposal decision. The PA is an analysis required by the Code of Federal Regulations (CFR), Title 40, Part 191 (40 CFR 191), which identifies the processes and events that may affect the disposal system (WIPP) and examines the effects of those processes and events on the performance of WIPP. A NMVP is required for the WIPP by 40 CFR 268 in order to dispose of land disposal restriction (LDR) mixed TRU waste in WIPP. It is anticipated that the detailed Resource Conservation and Recovery Act (RCRA) waste characterization data of all INEL retrievably-stored TRU waste to be stored in WIPP will be required for the NMVP. Waste characterization requirements for PA and RCRA may not necessarily be identical. Waste characterization requirements for the PA will be defined by Sandia National Laboratories. The requirements for RCRA are defined in 40 CFR 268, WIPP RCRA Part B Application Waste Analysis Plan (WAP), and WIPP Waste Characterization Program Plan (WWCP).

This Project Management Plan (PMP) addresses only the characterization of the contact handled $(\mathrm{CH})$ TRU waste at the INEL. This document will address all work in which EG\&G Idaho is responsible concerning the INEL WETP. Even though EG\&G Idaho has no responsibility for the work that ANL-W is performing, EG\&G Idaho will keep a current status and provide a project coordination effort with ANL-W to ensure that the INEL, as a whole, is effectively and efficiently completing the requirements for WETP.

The INEL WETP requires the coordinated efforts of numerous State and Federal agencies, U.S. Department of Energy (DOE) offices, and DOE contractors. In addition, it requires the coordinated efforts of many individuals of many disciplines including: management, engineers, scientists, statisticians, health physics personnel, and technicians. EG\&G Idaho is responsible for providing coordination between the INEL WETP and all external parties. Funding for the INEL WETP is provided by the Department of Energy (DOE)-Albuquerque Operations Office (DOE-AL)/WIPP Project Integration Office (WPIO). 


\section{OBJECTIVES}

The primary goal of WETP is to support the efforts of DOE in achieving a final disposal decision for WIPP. The INEL WETP has several projects with separate objectives that focus on this goal.

1. The objective of Operational Phase Waste Characterization is to collect waste characterization data of known and defensible quality on a statistically significant fraction of the readily retrieved stored TRU waste. These data will be used to support the disposal NMVP, development of the final WIPP RCRA Part B Application, and other DOE needs.

2. The objective of volutile organic compound (VOC) Transport Modeling is to collect sufficient data on drum headspace VOCs to enable DOE to define drum headspace representativeness as required in the WIPP No-Migration Determination (NMD). It is expected that this definition will demonstrate the measurement of drum headspace VOCs as a viable waste characterization tool. It is assumed that the proposed simulated waste experiments, actual TRU waste sampling, and VOC Transport Modeling will provide sufficient data. It is anticipated that these experiments and modeling will ultimately reduce the cost of TRU waste characterization by reducing the amount of required sampling and analysis.

3. The objectives of waste characterization technology developments are to enable the collection of waste characterization data of known quality and to develop techniques that improve the efficiency and reduce the cost associated with TRU waste characterization. 


\section{ORGANIZATION, RESPONSIBILITIES, AND AUTHORITY}

The INEL WETP organizational structure showing functional responsibilities, level of authority, and lines of communication for all activities associated with the WETP at the INEL is shown in Figure 3-1.

\subsection{DOE-ALWPIO}

The WPIO is responsible for approving and managing all activities related to the WETP. The WPIO reviews and concurs on all proposed experimental and supporting waste characterization activities to ensure that all regulatory and programmatic requirements are met. The WPIO is responsible for ensuring that all waste characterization data received at the WIPP are reviewed and validated, and that all records pertaining to waste characterization and the experimental program are managed and controlled according to the requirements of the Quality Assurance Program Plan (QAPP).

\subsection{DOE-Idaho Operations Office}

The Department of Energy Idaho Operations Office (DOE-ID) is responsible for providing an interface between the operating contractor (EG\&G Idaho), WPIO, the WIPP Waste Acceptance Criteria Certification Committee (WACCC) Chairperson, and Department of Energy Headquarters (DOE-HQ) to resolve any problems that can affect the quality of the program.

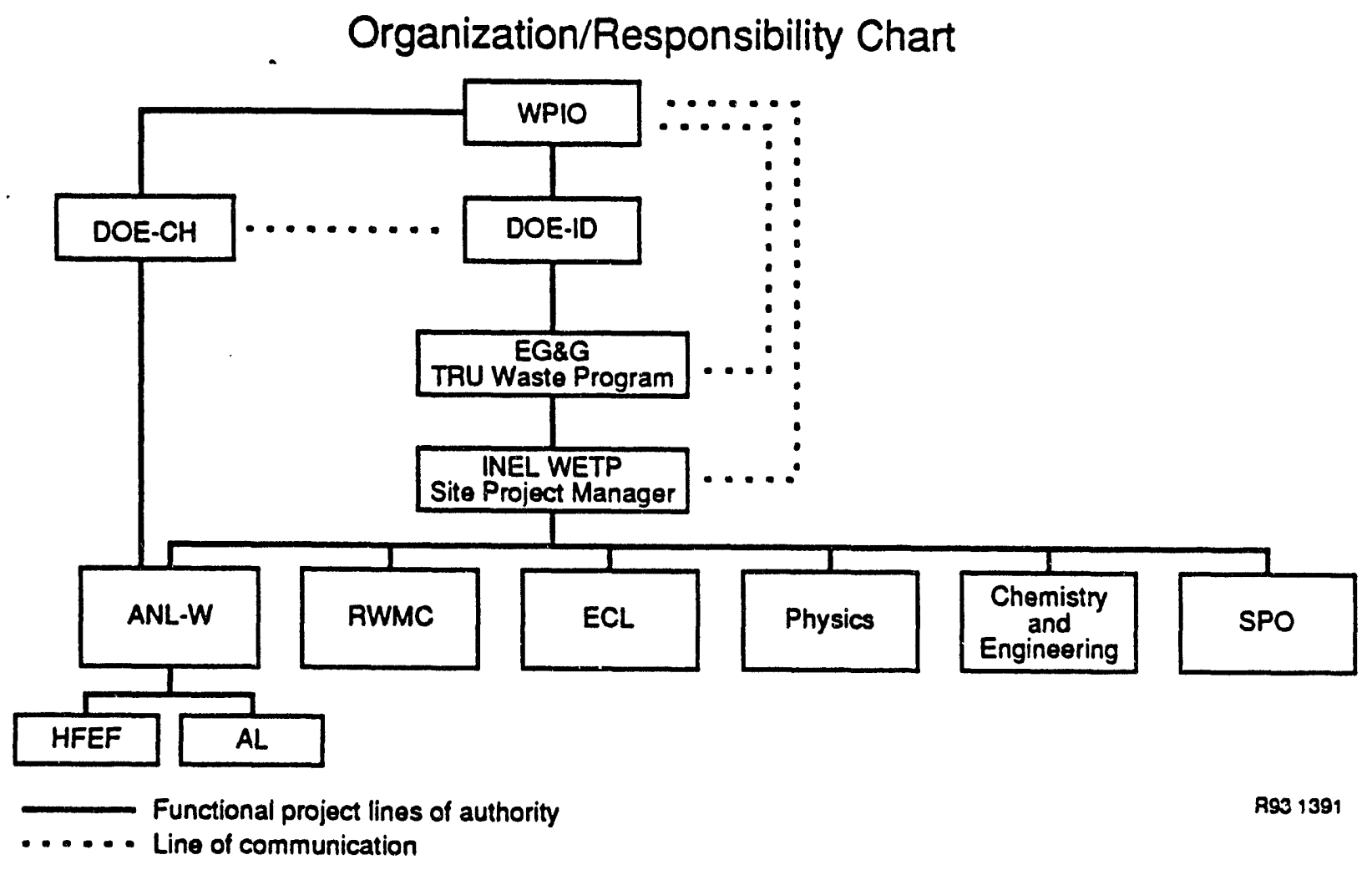

Figure 3-1. Organization responsibility chart. 
DOE-ID is also responsible for reviewing and approving the EG\&G Idaho WETP Program Quality Assurance Project Plans (QAPjPs) and their revisions. They are also responsible for ensuring that the requirements of the QAPjPs are in compliance with all DOE orders and that the resources and funding are available to accomplish this program.

\subsection{INEL WETP Site Project Office}

The Site Projection Office (SPO) is responsible for all operational aspects of the INEL WETP. The SPO provides a central location for the control and distribution of data generated for the WETP. The SPO consists of the Site Project Manager, the Site Quality Assurance Officer (SQAO), the Site Data Validation Officer, and the Site Document Control Office. The INEL QAPjP and WWCP QAPjP ${ }^{1,2}$ provide details of SPO activities and personnel responsibilities.

\subsection{Radioactive Waste Management Complex}

The Radioactive Waste Management Complex (RWMC) contains two of the facilities that support the INEL WETP. The Stored Waste Examination Pilot Plant (SWEPP) and the Drum Venting Facility (DVF). The SWEPP facilities is where the Passive Active Neutron (PAN), radioassay (RA), real-time radiography (RTR), the gamma scan analyses and the Transuranic Package Transporter-II (TRUPACT-II) loading activities are conducted. The venting of drums and headspace gas sampling (pre-filter and post-filter) are conducted in the DVF. All activities conducted in support of the WETP are described in the RWMC QAPjP ${ }^{3}$ and WWCP QAPjP. ${ }^{2}$

\subsection{EG\&G Idaho Environmental Chemistry Laboratory}

The Environmental Chemistry Laboratory (ECL) is responsible for the determination of selected VOCs contained in headspace gas samples taken from waste containers and bins. The ECL also supports sampling of bin headspace gas, conducts flammability testing, and assists in developing sampling techniques as required by WETP.

\subsection{EG\&G Idaho Engineering Research and Applications}

The EG\&G Idaho Engineering Research and Applications (ERA) Department is responsible for r-nviding the technical support necessary for the VOC Transport Modeling, the Carbon Cor ite Filter Study, sampling and analytical methods development, the Fourier Transform Infraı d (FT-IR) spectroscopy feasibility study, and RTR developments.

\subsection{EG\&G Idaho Nuclear and Radiation Physics}

The EG\&G Idaho Nuclear and Radiation Physics Unit is responsible for providing technical support necessary for conducting the nondestructive assay physics evaluation program as described in the WWCP QAPjP. 


\subsection{DOE-Chicago Operations Office}

The Department of Energy Chicago Operations Office (DOE-CH) is responsible for providing an interface between the operating contractor (ANL-W), WPIO, the WIPP WACCC Chairperson, and DOE-HQ to resolve any problem that can affect the quality of the program.

DOE-CH is also responsible for reviewing and approving the ANL-W WETP Program QAPjPs and their revisions. They are also responsible for ensuring that the requirements of tise QAPjPs are in compliance with DOE orders and that the resources and funding are available to aciomplish this program.

\subsection{ANL-W WETP Project Manager}

The ANL-W WETP Project Manager is responsible for all operational aspects of the INEL WETP Program conducted at ANL-W and shall oversee the implementation of the ANL-W QAPjPs at each of the ANL-W facilities [Hot Fuel Examination Facility (HFEF) and Analytical Laboratory (AL)]. Establish and maintain coordination with other WETP management (i.e., INEL SPO, DOE-ID, and DOE-AL/WPIO), to ensure accurate and complete implementation of the WETP requirements.

The ANL-W has two facilities that participate in the WETP Program. The HFEF conducts TRUPACT-II loading operations, drum and inner layer of confinement gas sampling, solidified waste sampling, and general waste examination. The AL performs gas (e.g., hydrogen and methane) analyses of headspace samples. 


\section{SCOPE OF WORK}

This section provides a description of all activities identified to accomplish the stated objectives. The Work Breakdown Structure (WBS) for this project is provided in Section 5 of this PMP.

\subsection{Operational Phase Waste Characterization}

The Operational Phase Waste Characterization will provide limited characterization data on 340 drums selected from the Certified and Segregated (C\&S) building. The characterization will include the nondestructive examination (NDE)/nondestructive assay (NDA), headspace gas sampling of drums at the SWEPP Facility, VOC analysis at the ECL, hydrogen analysis at the $\mathrm{AL}$, and final data reporting at the SPO.

\subsubsection{Drum Selection and Retrieval}

This activity involves the selection and retrieval of TRU waste from the SWEPP C\&S building. Selection is based on waste form [e.g., Item Description Code (IDC) or TRUPACT-II Content Code] and is described in Engineering Design Files (EDFs) that are generated by the TRU Waste Programs Unit. The drums will be retrieved in accordance to existing detailed operating procedures (DOPs) at the RWMC.

\subsubsection{Headspace/RTR/RA}

This activity includes the RWMC support for the NDE/NDA and headspace gas sampling of approximately 340 drums at SWEPP. NDE/NDA will include RTR and RA as required by the INEL WWCP QAPjP. Based on previous program examination results, it is expected that a portion of these drums will not be acceptable for shipment to WIPP. Headspace gas samples will be collected at the SWEPP or DVF and transported to the ECL. Reports detailing the results of RTR/RA will be sent to the SPO.

\subsubsection{Physics Evaluation}

This task supports development of integrated NDA methodologies, collection and review of gamma data, review of RTR data, review of PAN data, and determination of assay uncertainty. Activities also include Monte Carlo Neutron Photon simulations of PAN system response and development of NDA total error analysis. This evaluation will be completed in a minimum of $10 \%$ of all drums characterized.

\subsubsection{VOC Analysis}

This task includes the ECL activities required to support the preparation and evaluation of headspace gas samples for VOCs. Reports documenting the VOC analysis results will be submitted to the SPO. The ECL will participate in the WIPP Performance Demonstration Program (PDP) and maintain certification for VOC analysis. All activities will be $c_{1}$ nnducted in accordance with the ECL QAPjP and the INEL WWCP QAPjP. 


\subsubsection{Gas Analysis}

This activity includes the AL support for the preparation and analysis of headspace gas samples for hydrogen. Reports documenting the hydrogen analyses will be submitted to the SPO. The AL will participate in the WIPP PDP and maintain certification. All activities will be conducted in accordance with the AL QAPjP and the INEL WWCP QAPjP.

\subsubsection{Reporting, Validation, and Documentation}

The SPO will continue development and maintain approval status of documentation required to implement the Operational Phase Waste Characterization Program. The SPO is also responsible for generating individual drum data reports and subsequent transmittal to WPIO.

\subsection{VOC Transport Modeling}

VOC Transport Modeling will provide sufficient data to enable DOE to define VOC drum headspace representativeness. Data needed for this demonstration will come from laboratory-scale simulated waste experiments, VOC transport models, actual drum headspace and inner layer of confinement sampling, and transport modeling. A series of simulated waste drum experiments under different conditions and transport modeling will be performed. Sixty-six drums of actual TRU waste will be sampled and transport models will be developed to support this demonstration. All results will be documented in EDFs and Technical Reports.

\subsubsection{Drum Selection and Retrieval}

This activity involves the selection and retrieval of TRU waste from the C\&S Building. The selection is based on waste type and is described in EDFs generated by the ERA. Drums will be retrieved in accordance to existing DOPs at the RWMC.

\subsubsection{Headspace/RTR/RA}

Same requirements at identified in Section 4.1.2. All containers selected for VOC Transport Modeling must be acceptable for TRUPACT-II transport to ANL-W. Containers that do not meet this requirement will be utilized in support of Operational Phase Waste Characterization.

\subsubsection{Physics Evaluation}

Activities and requirements for this task are the same as in Section 4.1.3.

\subsubsection{Transport}

This activity supports the transport of the waste containers between the RWMC and ANL-W. The TRUPACT-II shipping container will be utilized for all shipments. 


\subsubsection{VOC Analysis}

Activities and requirements for this task are the same as in Section 4.1.4.

\subsubsection{Gas Analysis}

Activities and requirements for this task are the same as in Section 4.1.5.

\subsubsection{Reporting, Validation, and Documentation}

Activities and requirements for this task are the same as in Section 4.1.6. The SPO will transmit flammable VOC data and hydrogen data to the TRUPACT-II Transportation Certification Official in support of shipments between the RWMC and HFEF. The SPO will generate and send reports to the Chemistry and Engineering Group for use in VOC Transport Modeling.

\subsubsection{Simulated Waste Drums}

This task includes all simulated waste drum experiments and related activities performed by the Chemistry and Engineering Group at the Idaho National Engineering Laboratory Research Center (IRC). Quasi-steady state simulated waste drum experiments will be conducted using simulated IDC 003, sludge. VOC specific concentrations will be monitored for 12-16 weeks in multiple locations within four simulated drums. Data will be used to validate the VOC Transport Modeling. Experimental details and results will be documented in EG\&G Idaho Technical Reports.

\subsubsection{Permeation Study}

This task includes all permeation related experiments and related activities performed by the Chemistry and Engineering Group at the IRC. Permeation measurements will be determined on select VOCs using both polyvinyl chloride and low-density polyethylene. Permeabilities as a function of concentration will be determined. Permeability data will be used in VOC transport models. Experimental details and results will be documented in EG\&G Idaho Technical Reports.

\subsubsection{Modeling}

This task includes all modeling activities performed by the Chemistry and Engineering Group related to the ability to predict VOC transport within actual and simulated waste drums. Quasi-steady state VOC transport model will be developed utilizing simulated waste drum permeation data. This model will be adopted to predict VOC transport within actual waste drums. Actual and simulated waste drum data and modeling will be used to help define drum headspace representativeness. Actual drum sampling plans, VOC transport modeling, and drum headspace representativeness will be documented in EDFs, Technical Reports, or Position Papers, as appropriate. 


\subsection{Project Management/SPO}

This activity provides for the INEL WETP coordination, technical direction, project control, quality assurance (QA) and quality control (QC), document control, report generation (weekly, monthly, ad hoc), and the QAPP required facility audits.

\subsubsection{Technical Management}

This activity provides the technical management and coordination for the work being conducted to support the WETP. It involves oversight and technical direction of activities that are being conducted at EG\&G Idaho and ANL-W. Technical direction and oversight are also provided to subcontractors for the development of sludge sampling methods, analytical methods development, and QAPP revisions.

\subsubsection{Project Control}

This activity provides for the project administration services, cost, and schedule control. The support and input to the WIPP weekly reports, integrated monthly reports, mid-year and year-end reviews. Monthly Operation Review Meetings, program scheduling, resource loading and financial exercises, CR/PIP, Change Control Board (CCB), and activity data sheet (ADS) development.

\subsubsection{Facility Audits/QA/QC}

This task provides for the QAVQC of the WETP and the establishment of the SPO and associated functions. QAVQ activities will be conducted in accordance to American Society of Mechanical Engineers (ASME) Nuclear Quality Assurance (NQA-1), Element 3, the WIPP QAPP, Quality Program Plan (QPP)-400, and the INEL QAPjP. QCs for this project are required for both field and laboratory activities. Control of these activities shall be in compliance with ASME NQA-1, Elements 9 and 11. QC checks and their frequencies for various field operations and laboratory activities shall te specifically addressed in facility procedures.

The QAPP for the WETP requires that the participants' SQAO conduct two facility audits per year. In addition, WIPP.WACCC is to conduct an annual audit of each participants' facility. This task provides for these activities.

\subsubsection{Travel}

This task provides for the travel required to provide the technical coordination, project control, project cost, and schedule input required to support WPIO.

\subsubsection{Management Reserve}

There are no funds to ensure continued project progress while new fiscal year (FY) funding is being allocated or to provide funding for unexpected and unplanned changes in task that may occur, which are not of sufficient magnitude to require WPIO CCB action. 


\subsection{Deliverables}

The following deliverables have been identified for FY-1993.

Table 4-1. Operational phase waste characterization.

\begin{tabular}{ll}
\hline \multicolumn{1}{c}{ Task } & Due date \\
\hline Complete RTR enhancements & $04 / 01 / 93$ \\
Characterization and reporting of 255 drums & $09 / 30 / 94$ \\
Fabrication of two calibration drums & $06 / 01 / 94$ \\
Complete gamma measurements and physics evaluation 10\% of & $09 / 30 / 94$ \\
all drums & \\
Transport 20 sludge drums between ANL-W and RWMC & $09 / 30 / 94$ \\
Complete two facility audits & $08 / 31 / 94$ \\
\hline
\end{tabular}

Table 4-2. VOC transport modeling.

\begin{tabular}{ll}
\hline \multicolumn{1}{c}{ Task } & Due date \\
\hline Complete simulated waste experiments & $01 / 31 / 94$ \\
Issue simulated waste drum modeling report & $04 / 01 / 94$ \\
Complete polymer solubility study & $11 / 30 / 94$ \\
Issue actual waste drum modeling report & $09 / 30 / 94$ \\
Prepare (RTR/RA) and transport 66 drums for VOC Transport & $09 / 30 / 94$ \\
Modeling & \\
\hline
\end{tabular}

Table 4-3. Waste characterization technology development.

\begin{tabular}{ll}
\hline \multicolumn{1}{c}{ Task } & Due date \\
\hline Complete development of FT-IR System & $01 / 31 / 93$ \\
Complete FT-IR field study at ANL-W & $07 / 01 / 94$ \\
Issue FT-IR Field Study Report & $08 / 15 / 94$ \\
Issue draft TRU Waste Characterization QAPP & $03 / 04 / 94$ \\
\hline
\end{tabular}


Table 4-4. Program management.

\section{Task}

Provide weekly, monthly, and mid-year and ad-hoc reporting

Provide project coordination and technical support.

\subsection{Requirements and Constraints}

This PMP is based upon the following items:

1. All work will be completed in accordance with applicable Federal, State, DOE-HQ/DOEID; and EG\&G Idaho laws, regulations, and procedures. These include, but are not limited to:

- 40 CFR 191.3 (1990), Requirements of the Conditional NMD for the Test Phase ${ }^{4}$

- RCRA EPA SW-846

- QAPP, Revision 1 for the WETP

- WIPP Waste Acceptance Criteria (WAC) document ${ }^{5}$

- $\quad$ TRUPACT-II Safety Analysis Report for Packaging (SARP) ${ }^{6}$

- Requirements imposed by the WAP in the WIPP RCRA Part B Permit Application ${ }^{7}$ that was submitted to the Ncw Mexico Environmental Department under 40 CFR Parts 264 and 265 (governing the operation of the WIPP as a treatment, storage, or disposal facility for hazardous waste)

- INEL WETP Project Directives (PDs)

- INEL QAPjPs for RWMC, ECL, INEL SPO, ANL-W HFEF, and ANL-W Laboratory

- EG\&G Idaho Company Procedures Manual

- Waste Management Department PDs

- $\quad$ TRUPACT-II Certificate of Compliance 9218

- DOE Order 5820.2A, "Transuranic Waste Storage Treatment and Disposal" 
- Environmental Restoration and Waste Management Department Training Program Manual

- QPP-400, Quality Program Plan for the Transuranic Waste Programs Unit

- EG\&G Idaho Safety Manual

- EG\&G Idaho Radiological Controls Manual

2. All reports will be sent to WPIO.

3. All reports will be on a drum basis and will be in summary format.

4. Both pre-filter and post-filter samples will be collected at SWEPP.

5. SWEPP will process $20 \%$ more drums for the VOC Transport Modeling than specified in EDF Number RWMC-576.

6. Two TRUPACT-II trailers and six TRUPACT-II containers will be available at INEL.

7. Waste Type II and III drums will be repackaged into new 55-gal drums.

8. Samples collected at the HFEF will be analyzed for VOCs and hydrogen.

9. HFEF will send samples to ANL-W/AL on a weekly basis.

10. ANL-W/AL will send samples to EG\&G Idaho ECL within 14 days of validated time of sample receipt.

11. AL turnaround time will be 28 days for samples collected at HFEF.

12. AL turnaround time will be 21 days for samples collected at SWEPP.

13. Samples collected at SWEPP will be sent to ECL for transfer to ANL-W.

14. All laboratory reports will be in summary format.

15. ANL-W/AL and EG\&G ECL required to perform all QAVQC activities as specified in the latest approved WIPP QAPP (QAPP, Revision 1).

16. Waste sclected for the VOC Transport Modeling must comply with the TRUPACT-II payload requirements.

17. Work performed in support of the INEL WETP must conform to the applicable facility operational safety requirements and environmental permit limitations. 


\subsection{Assumptions}

\subsubsection{Operational Phase Waste Characterization}

- WPIO approves WWCP QAPjP as submitted

- Drum headspace gas sampling, RTR, and RA 15 drums biweekly

- $\quad$ All C\&S building drummed TRU inventory available

- $\quad$ ANL-W WCC available for sludge coring and sampling 06/01/94.

\subsubsection{VOC Transport Modeling}

- No Sandia National Laboratories Bin Test requirements will be implemented

- WCC will not be available until 12/01/93

- Waste Type I drums will be overpacked into standard waste boxes after sampling

- Waste Type II and III sampling will required utilization of the WCC

- Additional program requirements and QAVQC requirements will be specified in the QAPP for the WETP.

\subsubsection{Waste Characterization Technology Development}

- $\quad$ ANL-W is responsible for WCC sludge sampling design requirements

- Full EPA SW-846 cross validation not required for evaluation of fingerprinting methods development

- TRU Waste Characterization Program Plan not required for initial development of TRU QAPP

- Completion of FT-IR field study assumes ANL-W completes all 44 drums of Type II/III waste required for VOC Transport Modeling before 07/01/94

- Completion of RTR enhancement task assumes RWMC/SWEPP has engineering support required to complete installation of new hardware.

\subsubsection{Project Management}

- WPIO will require monthly Earned Value reporting

- WPIO will require mid-year and year-end project reviews 
- WPIO will require ad-hoc reporting as needed.

\subsection{Specifically Excluded Scope}

The following work has been excluded from the cost and schedule estimate for this project.

\subsubsection{Waste Matrix}

Manipulation of the waste matrix will not be performed at the RWMC.

\subsubsection{Affected Scheduled Facility Projects}

Activities that will affect scheduled facility projects (e.g., Line-Item Construction or environmental restoration) will be evaluated for programmatic impacts.

\subsubsection{Boxed Waste}

Boxed waste at the RWMC will not be used to support the Bin Loading Operations.

\subsubsection{Earthen-Covered Storage}

Waste in earthen-covered storage at the RWMC will not be retrieved for use in the WETP.

\subsubsection{Waste Containers}

Waste containers cannot be opened and inspected at the RWMC until the Waste Characterization Facility is online. 


\section{WORK BREAKDOWN STRUCTURE}

The WBS (Figure 5-1) identifies the activities associated with the performance of the project. Included in this diagram are the cost estimates (e.g., RTR/RA at SWEPP and VOC analysis at ECL) and title for each major task and associated activities. Because similar activities are associated with multiple tasks, work packages are generated based on similar activities and not tasks.

Work packages and associated costs for these activities are as follows:

Table 5-1. Work packages and associated costs.

\begin{tabular}{lc}
\multicolumn{1}{c}{ Title } & $\begin{array}{c}\text { Funds } \\
\text { (\$K) }\end{array}$ \\
\hline Drum examination and retrieval & 1,373 \\
Evolved VOC transport modeling-WIPP & 236 \\
WETP-ECL & 1,259 \\
Waste Characterization Technology Development & 782 \\
SPO & 1,128 \\
\hline
\end{tabular}


Work Breakdown Structure

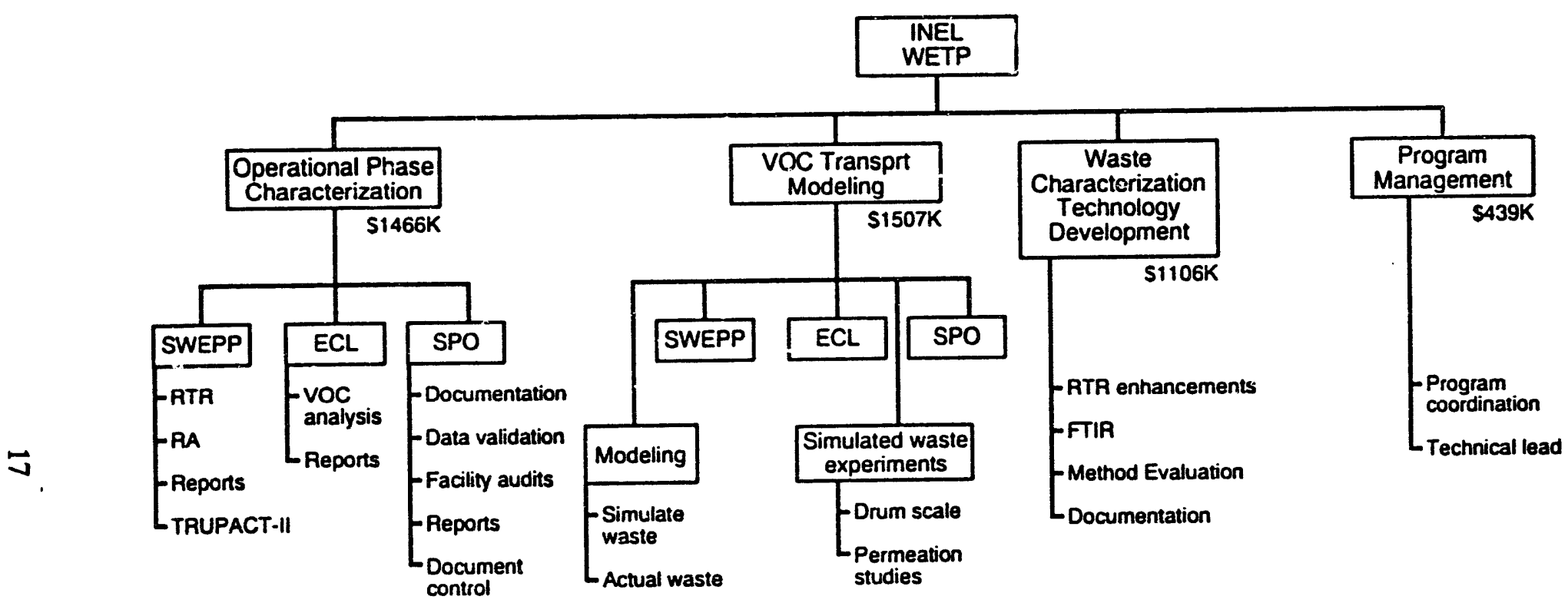

Figure 5-1. Work breakdown structure. 


\section{SCHEDULE}

The schedule for this project is shown as Figure 6-1. The schedule is at the activity level for each subtask with the capability of rolling up to major tasks such as Bin Loading, VOC Transport Modeling, Operational Phase Waste Characterization, and Waste Characterization Technology. Upon approval of this PMP, these schedules will become the baseline schedule. Project progress will be measured by comparing the progress to date (maintained on a current or working schedule) with the estimated progress. 


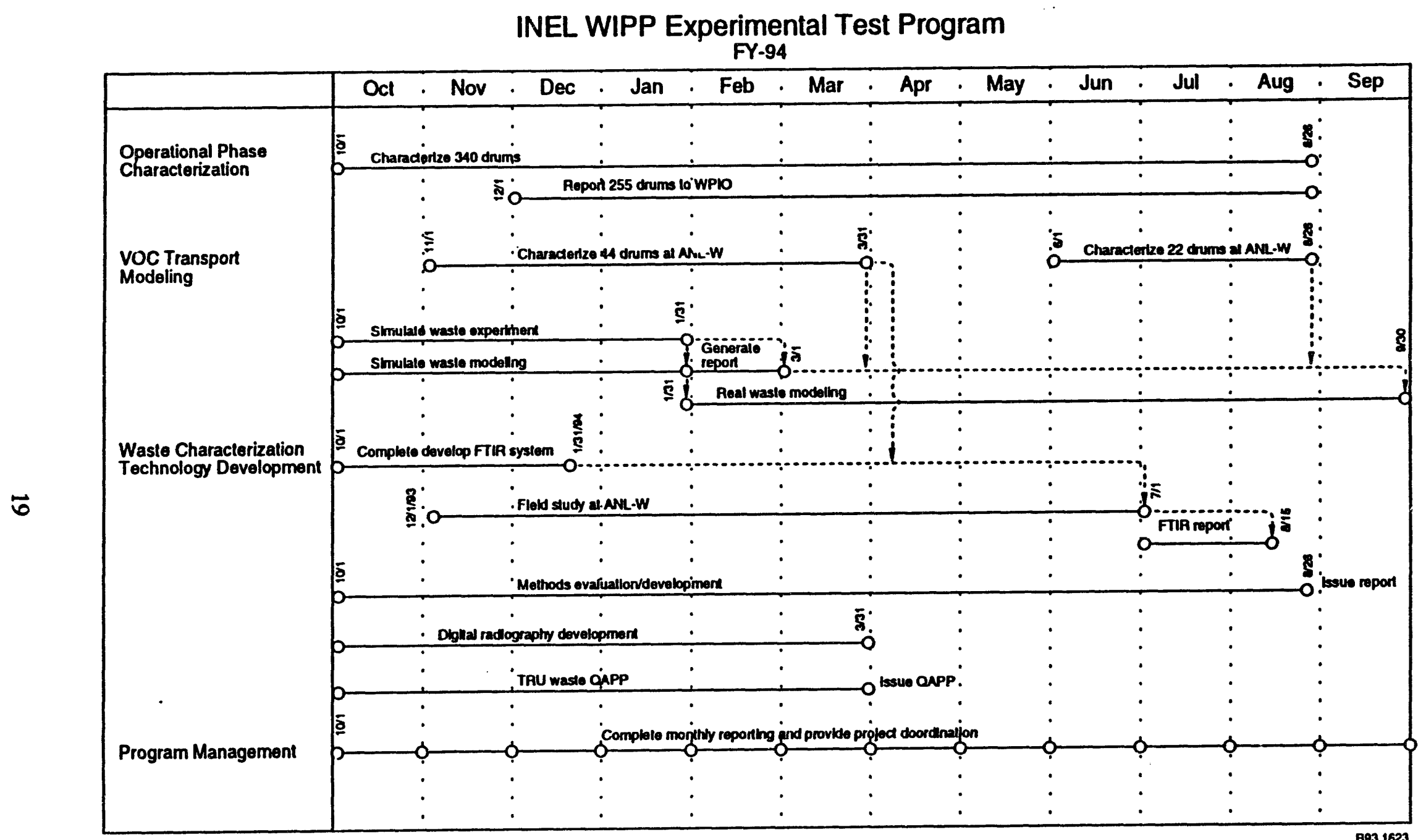

Figure 6-1. INEL WETP schedule. 


\section{LOGIC DIAGRAM}

The schedule shown in Figure 7-1 shows the relationship between activities for the overall project and tasks. This schedule shows the interconnections and constraints between activities and task. 
INEL WIPP Experimental Test Program

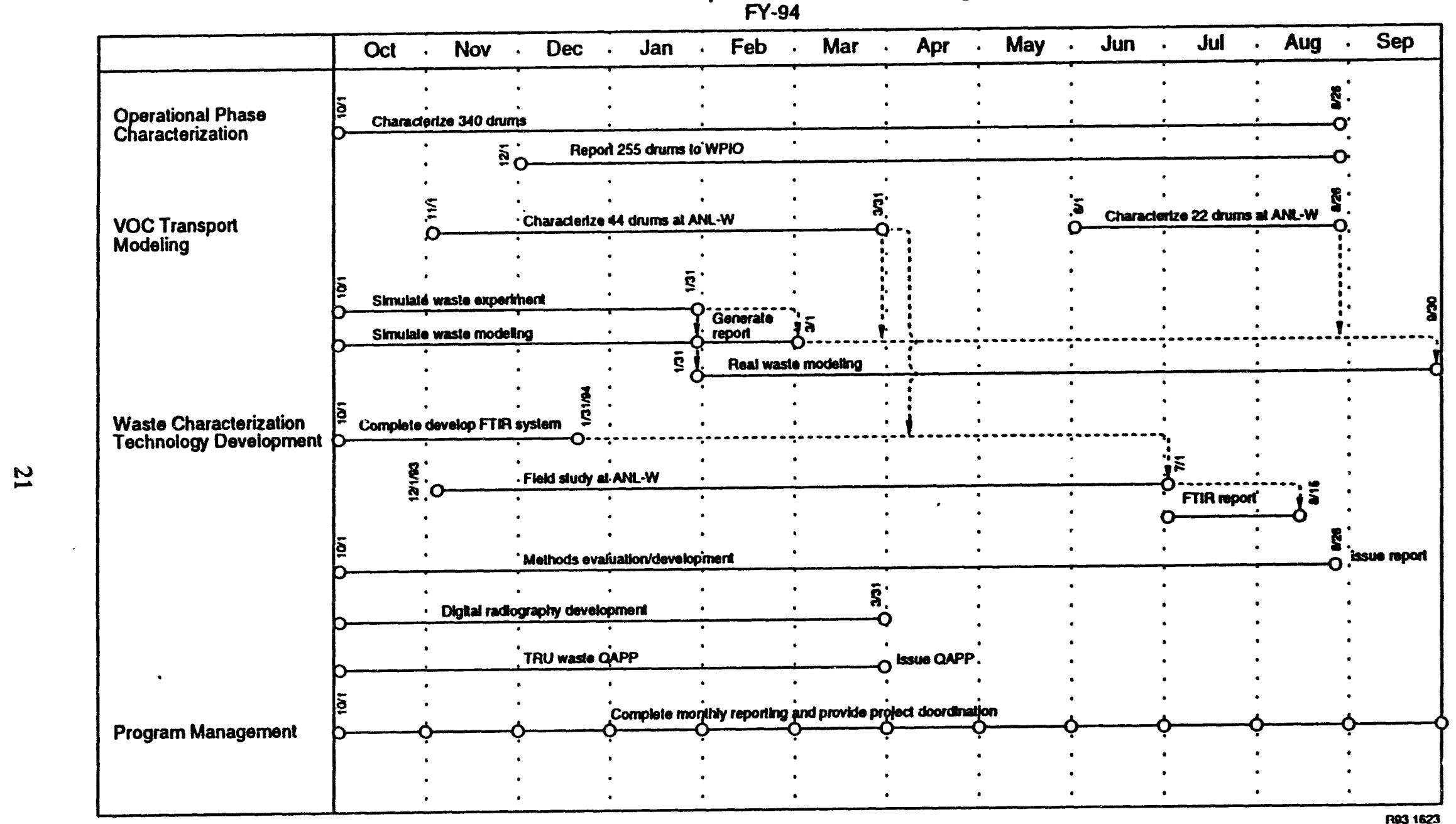

Figure 7-1. INEL WETP logic diagram. 


\section{PERFORMANCE CRITERIA}

Detailed performance criteria is established in the EG\&G Idaho WIPP planning packages Task Description Documents (TDD) and work packages, and the WIPP Project Integration Office Integrated Project Management System document. Some of the criteria contained in these documents are listed below.

- EG\&G Idaho is to provide the interface and coordination of the WETP at INEL

- EG\&G Idaho will provide technical support for the WIPP Program and the INEL facilities that support WETP

- The INEL WETP Program will develop the WIPP QAPP and revision

- Sampling methodology and procedures will be developed under the guidance of INEL WETP

- INEL WETP will provide project office support for Level II data validation of the experimental test data, program document control, and QAVQC as required by the WIPP QAPP

- Laboratory certification and examination capabilities will be maintained to support the WETP

- The program will ensure that certification and transportation capabilities are maintained at RWMC. 


\section{COST AND MANPOWER ESTIMATES}

The EG\&G Idaho total WIPP related budget for FY-1994 is $\$ 4,668 \mathrm{M}$. This is comprised of \$3,568K FY-1994 Budget Authorization and \$1,100K FY-1993 carryover. \$166K is to be identified as Capital Equipment (CE) and \$O for General Plant Projects. Manpower for FY-1994 is 36.5 fulltime equivalents composed of 32.5 contractor personnel and 4.0 subcontract personnel. The estimated budget for FY-1995 is $\$ 4,542 \mathrm{~K}$, which is comprised of $\$ 4,467 \mathrm{~K}$ Operating Funds and $\$ 75 \mathrm{~K}$ of $\mathrm{CE}$.

Costs and resources have been applied against the tasks identified in the project schedule baseline (see Section 7). Earned value reporting will be conducted in accordance with EG\&G Idaho ER\&WM Department and DOE-AL/WPIO requirements. 


\section{PROJECT FUNCTIONAL SUPPORT REQUIREMENTS}

The DOE-ID provides coordination, communication, and support as directed by DOE-HQ between DOE-AL and EG\&G Idaho WETP. Technical support to the WIPP Program and the INEL facilities that support the INEL WETP is provided by the SPO.

The specific function and authority of key individuals involved in the INEL WETP are described in the INEL, RWMC, ECL, ANL-W/HFEF, and ANL-W/AL QAPjPs and the INEL WETP PDs. 


\section{PROJECT MANAGEMENT, MEASUREMENTS, AND PLANNING AND CONTROL SYSTEMS}

The INEL WETP will operate in accordance with the intent of DOE Order 4700.1, "Project Management System" and N4700.5, "Project Control System Guidelines" as implemented by EG\&G Idaho Company Procedures Manual, Section 20. Appropriate management and control systems will be implemented for each WBS work element. The INEL WETP Project Manager has the authority and responsibility to develop and maintain management planning, measurement and control criteria, and applicable procedures.

The PMP is the administrative baseline document for the INEL WETP and is modified only through the Change Control process. Technical baselines, WBS, costs, schedules, performance measurements, Change Control process, and management control system are put in place by the PMP, ADS, Task Description Documentations, and work packages. General project management responsibilitics are defined for the INEL WETP in the INEL, RWMC ECL, ANL-W/HFEF, and ANL-W/AL QAPjPs, and WETP PDs.

An approved financial plan, which authorizes funds for the EG\&G Idaho WETP Program must be in place before the initiation of any work. Work packages must be in place and approved by DOE-ID and the INEL WETP Project Manager before beginning any work. Monitoring of the INEL WETP work packages will be done using the following tools and processes.

- Cost and planning system labor hours and nonlabor hours distribution report to document actual hours and material dollars charged weekly

- Projected and expended cost comparison curves to display work packages cost-to-schedule performance

- Weekly monitoring of actual cost and understanding commitments

- Monthly status of work packages and WBS activities to show progress to completion.

Change control for baseline (cost, scope, and schedule) within the INEL WETP Program is provided by means of a CCB, which has been established by the INEL Waste Management Operations Program Management Plan, DOE-ID-10332. The purpose of the CCB is to control change to the INEL WETP bascline (customer-directed and/or agreed-upon changes to the project effort), document internal changes to the performance measurement baseline, and prohibit retroactive changes to records pertaining to work performed.

All INEL WETP activities will comply with pertinent regulatory, environmental, health and safety, security, and QA requirements. Compliance will be based on DOE orders, DOE directives, and internal policies and procedures.

Operations to be conducted at any INEL facility will be conducted in accordance to the sitespecific opcrating requirements of the facility at which the operations are being conducted.

Any exception to the use of the project management system will be identified elsewhere in the PMP, including special requirements, if such exception applies to a given section or element of this plan. 


\section{INFORMATION AND REPORTING}

\subsection{Reporting Requirements}

The WETP will operate in accordance with the intent of DOE Order 1332.1A, "Uniform Reporting System"; EG\&G Idaho Resource Manual, Section 10, "Documentation System"; WIPP QAPP, Section 8, "Data Reduction, Validation, and Reporting"; INEL QAPjP, Section 8, "Data Reduction, Validation, and Reporting", and Section 14, "Quality Assurance Reports to Management"; and WIPP Experimental Bin Test Program, Section 2.2, "Variance and Non-Conformance Reporting." These documents control processing of status reports, internal and formal reports, program reviews, and formal and informal communications.

\subsection{WETP Weekly and Monthly Reports}

The WETP has additional reporting requirements to effectively monitor and dociment programmatic activities. Monthly reporting will take place at the Technical Description Document level providing status relative to established project cost, schedule, and technical baseline. Cost or schedule variance reports of $\pm 10 \%$ and $\pm \$ 50 \mathrm{~K}$ for cumulative totals will require analysis of cause, impact, and corrective action.

Formal weekly reports will be transmitted to WPIO through DOE-ID. Contents will include weekly accomplishments, drum and bin status, non-INEL support requirements, and scheduled meetings.

Reporting requirements will be included in the work package with functional support staff from other organizations with the Company.

\subsection{Program Review}

In addition to the reporting documentation delineated above, WETP will conduct mid-year and year-end program reviews for WPIO. Program reviews are required to address: (a) goals established and goals accomplished, (b) detailed status and results of work completed, (c) specific plans for future work and/or goals, (d) updated resource and schedule projections, (e) variance analysis for the project baseline (cost, schedule, and technical progress), and ( $f$ ) issues/concerns.

\subsection{Formal and Informal Communications}

Formal and informal communications are encouraged between the INEL WETP and performing organizations to discuss issues and promote technical progress. All formal correspondence shall be directed between the WETP Site Project Office Project Manager and performing organizations.

Formal correspondence between the INEL WETP and DOE-AL/WPIO shall be through DOEID unless otherwise directed by DOE-ID. Formal correspondence shall be conducted by transmitting formal letter: to DOE-ID with draft letters attached for their use in transmitting to DOE-AL/WPIO. 


\section{SYSTEM ENGINEERING MANAGEMENT PLAN}

No formal systems engineering is planned for the INEL WETP. Informal systems engineering will be employed on a case-by-case basis as the need arises. All tasks of the INEL WETP shall be evaluated for potential application of system engineering techniques and practices in accordance with DOE Order 4700, "Project Management System." The extent to which systems engineering will be utilized depends on the complexity of the task, consequences of failure to meet project objectives, and the consequences of failure. 


\section{CONFIGURATION MANAGEMENT}

Configuration Management for the INEL WETP will be implemented in accordance with EG\&G Procedure 2.20, "Design Process and Requirements," 2.21, "Document Control," 20.23, "Configuration Management," the WIPP QAPP, the INEL QAPjP and the Waste Management Facility Configuration Management Plan to ensure that all facility documentation is properly maintained, and controlled. 


\section{CONTINGENCY}

Contingency funds for the INEL WETP will be held by the INEL SPO. This contingency will be used for FY prefinancing and unplanned work package task changes which are either caused by changes in scope or program direction and which do not exceed the dollar amount at which a CCB is to be created for the WPIO for review and approval. There are no contingency funds identified for FY-1994. 


\section{QUALITY ASSURANCE}

All INEL WETP activities will be conducted according to prescribed quality standards. An effective quality assurance program will be implemented and maintained, consistent with EG\&G Idaho Quality Manual, DOE Order 5700.6C on quality assurance, American National Standards Institute/ASME, (NQA-1), EPA, WIPP QAPP, INEL QAPjPs, WETP PDs, and QPP-400. 


\section{UTILITY SERVICES}

Not applicable to this project. 


\section{DECISION RESPONSIBILITY MATRIX}

All requisite information is provided in Section 3 of this PMP; WIPP QAPP; INEL, RWMC, and ECL QAPjPs; WIPP WETP PDs; and the TRU Waste Programs QPP-400. 


\section{ENVIRONMENTAL PLAN}

Each participating facility is required to maintain compliance with all applicable environmental regulations. Maintenance of facility compliance is not funded by this project. 


\section{HEALTH AND SAFETY PLAN}

A key responsibility of all WIPP Experimental Test Program staff is compliance with all environmental, safety, and health (ES\&H) requirements. All activities shall address ES\&H considerations; and plans shall be developed that allow for preparation, review, and approval of ES\&H documents, including, but not limited to, environmental checklists, environmental assessments, unreviewed safety questions, safety analysis revision, RCRA evaluations and permits, and national emission standards for hazardous air pollutants documentation.

All activities of the INEL WETP will adhere to the EG\&G Idaho Safety Manual, the RWMC Safety Analysis Report, and will be in accordance with DOE Order 5481.1B. 


\section{SECURITY PLAN}

All INEL WETP activities will be conducted in accordance with INEL security requirements. Security arrangements for personnel access will meet all applicable security requirements of the EG\&G Idaho Safeguards and Security Manual. Work conducted at the RWMC and the ECL will be in accordance to the facility's security plan.

At any other facility where work is to be performed, security shall follow the plan that is current for that facility. Where no such plan exists, or does not cover the specifics of the work to be performed, a Facility Security Plan will be written and issued before starting the work in accordance to the EG\&G Idaho Safeguards and Security Manual. 


\section{TECHNOLOGY TRANSFER}

Applicable topics for technology transfer include FT-IR, RTR enhancements, and Physics evaluations. This information will be transferred between participants in the program, other DOE sites, and private industry. These topics will be documented and retained in the WETP Project Office files. 


\section{DATA QUALITY PLAN}

Data quality will be in accordance to the WETP QAPP, INEL QAPjP, and PD. It will be monitored by the SPO Data Quality personnel. 


\section{ACQUISITION AND ASSISTANCE PLAN}

This will be performed in accordance with EG\&G Idaho Quality Manual. 


\section{TEST AND EVALUATION PLAN}

1

Testing and evaluation plan are discussed in the INEL QAPjPs EDFs and other EG\&G Idaho documentation as needed. 


\section{REFERENCES}

1. D. Sayer, EG\&G Idaho, Inc., "INEL Site Project Office Quality Assurance Project Plan for the Waste Isolation Pilot Plant Expcrimental Test Program," EGG-WM-9526 6,20 91.

2. A. Hayes, EG\&G Idaho, Inc., "Quality Assurance Project Plan for the INEL WIPP Waste Characterization Program," EGG.WM-10667.

3. D. Sayer, EG\&G Idaho, Inc., "Radioactive Waste Management Complex Quality Assurance Project Plan for the Waste Isolation Pilot Plant Experimental Test Program," EGG-WM-9527.

4. U.S. Environmental Protection Agency, 1990, "Conditional No-Migration Determination for the Department of Energy Waste Isolation Pilot Plant (WIPP)," Title 55, Federal Register, No. 47700 (55 FR 4700), November 14, 1990.

5. U.S. Department of Energy, "Waste Acceptance Criteria for the Waste Isolation Pilot Plant," DOE/WIPP-069, Revision 4.

6. Nuclear Packaging, Inc., "Safety Analysis Report for the TRUPACT-II Shipping Package, TRUPACT-II SAR."

7. U.S. Department of Energy, "Resource Conservation and Recovery Act, Part B Permit Application," DOE/WIPP 91-005. 

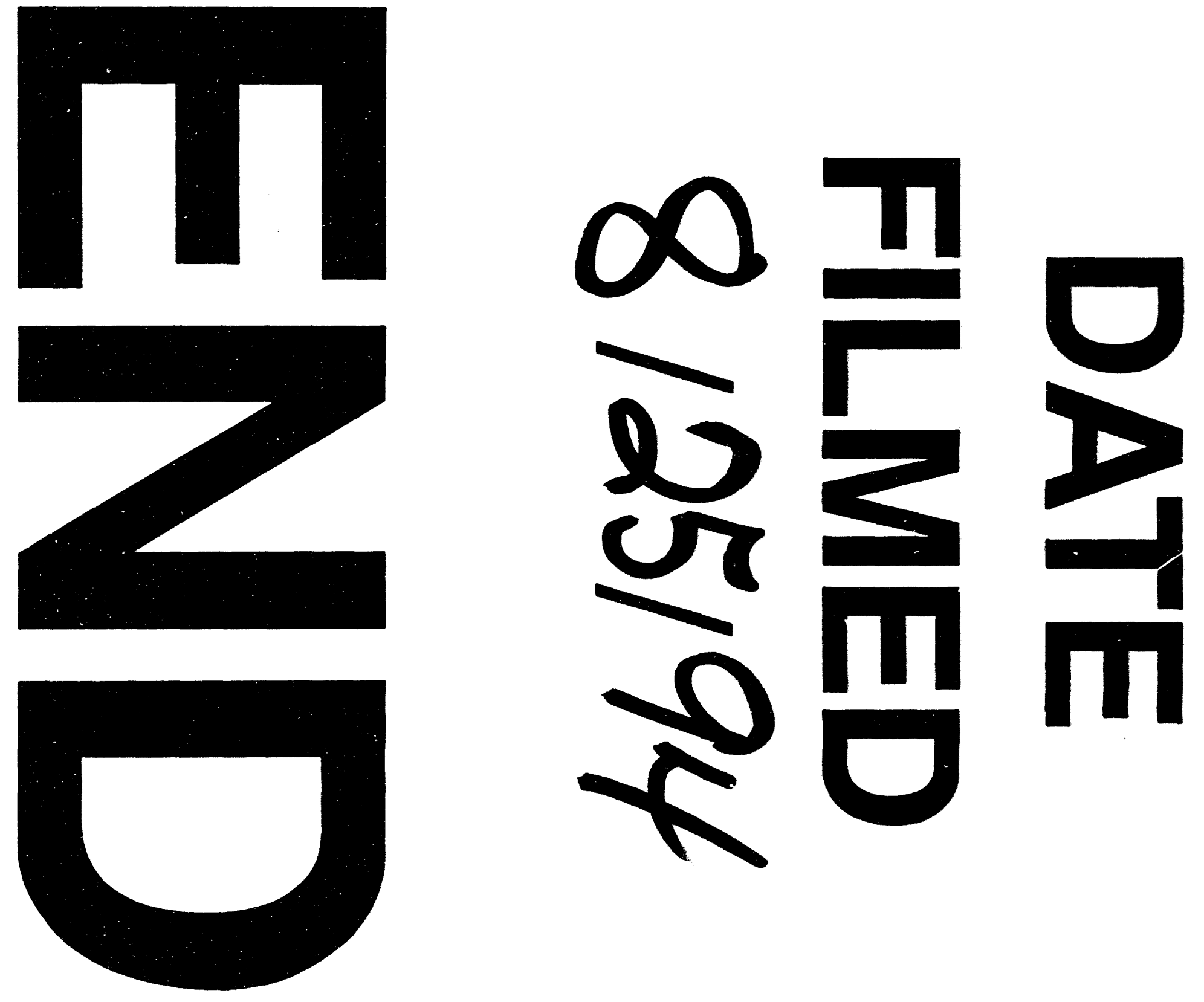

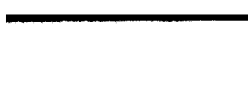

$-$

(1)

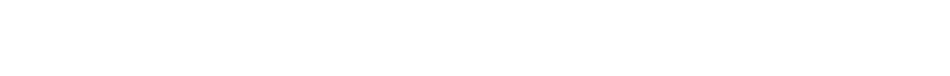

(1)

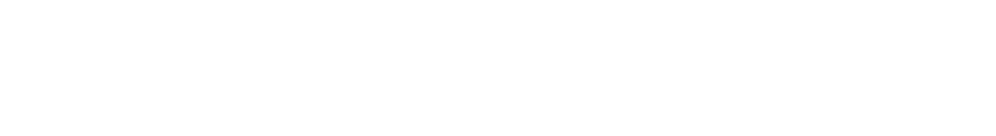

